\title{
Perspective of Clients and Healthcare Professionals About Occupational Therapy Intervention in Vocational Rehabilitation: A Descriptive-Exploratory Study at a Professional Rehabilitation Centre in Portugal
}

\author{
Jaime Ribeiro $^{1,2,3,4(\triangle)}{ }^{(\mathbb{D})}$, Andreia Inácio ${ }^{1}$ (D), Liliana Teixeira ${ }^{1}$ (D), \\ Inês Pereira ${ }^{1}$, Inês Lopes ${ }^{1}$, and Iolanda Gonçalves ${ }^{1}$ \\ ${ }^{1}$ School of Health Sciences, Polytechnic of Leiria, Leiria, Portugal \\ jaime.ribeiro@ipleiria.pt \\ ${ }^{2}$ Health Research Unit (UIS), Polytechnic of Leiria, Leiria, Portugal \\ ${ }^{3}$ Inclusion and Accessibility in Action Research Unit (IACT), \\ Polytechnic of Leiria, Leiria, Portugal \\ ${ }^{4}$ Research Centre Didactics and Technology in Teacher Education-CIDTFF, \\ University of Aveiro, Aveiro, Portugal
}

\begin{abstract}
Vocational rehabilitation (VR) allows individuals to enter, return and/or maintain employment. After literature review, no evidence of VR in individuals with acquired injuries, in Portugal was found. This paper aims to explore and describe the Occupational Therapy (OT) approach in VR and the client's and the healthcare professionals' perspectives, at Centro de Reabilitação Profissional de Gaia. A case study research was carried out with individuals aged 18 to 65 years old, with physical and neurological injuries, and receiving OT intervention; Occupational Therapists and other healthcare professionals working with those clients. To collect and analyse the data, a semi structured interview, focus group and subsequent content analysis by Bardin method were done. Participants' perspectives were that OT promotes autonomy in occupations, assesses and recommends assistive products and performs functional assessments. Comparing results with literature, the clients and health professionals' perspective of the OT intervention was consistent with the Occupational Therapist skills and intervention in VR.
\end{abstract}

Keywords: Vocational rehabilitation · Occupational Therapy • Employment • Acquired injury $\cdot$ Occupation

\section{Introduction}

Work as an area of occupation consists of paid employment, work interests, job and employment search, job performance, retirement preparation, and volunteering exploration and participation [1]. A job gives independence, because people can care for themselves and their dependents [2]. It is associated with better quality of life and 
allows the development of meaningful social activities [3]. On the other hand, unemployment or inability to return to work is associated with isolation and depression, due to income loss and stress increase [4]. Therefore, in populations with disability that cannot work, returning to work is essential [5-7] but difficult, due to the lack of information about adaptations and alternatives that may allow them to perform tasks that would be difficult or impossible otherwise [8].

Disability is a complex and broad concept, that includes different levels of functional limitations related to the person and their environment $[5,9,10]$. People with disabilities are capable of working in any context if their skills, limitations and adjusted strategies to workplaces are taken into account [11]. In many cases disability is acquired in adulthood, when the person is already working. Disability prevention, reintegration and job adjustment are matters that concern any organisation that does not have disabled workers [8].

Occupational Therapy (OT) and its field of action are still relatively unknown to the majority of the Portuguese population. A physiotherapist or a nurse are easily characterised, however with the Occupational Therapist there are still uncertainties, not knowing where the occupational in the name comes from. It is observed that many still do not take advantage of the services of these professionals either by the general lack of knowledge or by the unfamiliarity of other professionals and therapeutic decision makers.

When it comes to Vocational Rehabilitation (VR), this situation worsens, since many (including professionals) are also unaware of the existence of these services and specialised professionals in occupational science, as are the Occupational Therapists. It is in the public interest to educate people in general and health professionals for this possibility.

An essential element of the VR process is helping the person to become aware of their injury, disability or health condition in order to understand the balance between functionality and disability to manage their influence on occupational participation in work [2]. Thus, the first step in the OT process is to assess the capabilities and significant occupations of the individual, towards adapting the environment and activities to the person.

OT allows individuals to participate and be involved in occupations, through task analysis and identifying, removing or adjusting mobility and/or access to information barriers $[12,13]$. This can be achieved through specifically aimed intervention to regain function or using bespoke assistive products to compensate a reduced or inexistent function.

An assistive product consists in any product, instrument, equipment, or technical system, used by a person with a deficit, specially produced to prevent, compensate or neutralise the functional or participation limitation [14], prescribed by the multidisciplinary team [15]. Using assistive products in the workplace requires specific personalised adaptations to each person. Therefore, a careful assessment is made, that connects individual and their work conditions [8].

There are health facilities and other institutions that provide vocational rehabilitation services to restore people's abilities, allowing them to become as independent as possible [16]. Vocational rehabilitation consists in services that help to enter, return and/or maintain a job [12, 17], through interventions such as needs assessment, coaching, workplace adjustment and disability awareness [2, 13]. Anyone who has a 
problem in occupational performance, due to illness or injury, and wants to return or increase work quality may benefit from a vocational rehabilitation programme [18].

Occupational Therapists are distinctive in vocational rehabilitation, since they have a broad knowledge and a holistic perspective of physical and psychosocial sciences, activity analysis and organisational behaviour [12, 13, 17].

In a broad way, Occupational Therapists can assume a pivot role regarding the assessment, occupational performance improvement, career exploration, work adaptations, work conditioning, return to work planning, counselling, employers' training $[12,19,20]$; and act like a bridge between employers, physicians, clients and others involved in the rehabilitation process $[2,21]$.

After a critical revision, no literature was found regarding vocational rehabilitation of individuals with physical and neurological conditions in Portugal. Thus, we aimed on answering the research question "What are the clients and the healthcare professionals' perspectives about OT in vocational rehabilitation in physical and neurological conditions?". A qualitative approach through a case study with exploratory and descriptive goals was used to answer the question above.

The Centro de Reabilitação Profissional de Gaia (CRPG) is a public entity, resulting from the cooperation between the Instituto de Emprego e Formação Profissional (IEFP), Associação de Deficientes das Forças Armadas and the Cooperativa para a Educação e Reabilitação de Cidadãos Inadaptados de Gaia [22]. CRPG clients are people with disability, their families, employers and public work services, promoting active citizenship and quality of life [22]. The institution has social and professional rehabilitation services, qualification/education support, workplace endorsement (awareness, assessment and guidance for qualification and work; promoting recruitment; after-recruitment follow-up; assessment of workplace adaptations needs), finding solutions within public responses that promote work and self-care products (advisement and assessing; production and commercialisation) [22].

It is of interest to say that this study also aims to advance understanding about the role of the Occupational Therapist in this type of services in order to review, develop, and deliver services that provide outstanding health benefits for the people they work with. Furthermore, it seeks to appraise Occupational Therapists' perceptions of their participation in different modalities, in order adjust interventions and interactions with clients and team members to deliver the best service possible. Thus, it acquires great relevance as the occupation and the experience of their clients in all settings must be a concern of the Occupational Therapist.

We must always keep in mind that the practice of OT is based on a dynamic interaction with clients, so it is important to understand their feedback on the benefit of the intervention they receive. Investment in a qualitative study appears to have a good return to the extent that the "findings from qualitative descriptive studies are also readily conveyed by Occupational Therapists to clients or other team members without them requiring an understanding of a theoretical orientation in order to comprehend the findings" [23, p. 34]. 


\section{Ethic Procedures}

CRPG authorised the study and all participants read and signed an informed consent to participate in the study and for recording the interview (video and audio).

\section{Methods}

Qualitative research is used to obtain in-depth participants meanings, representations, symbolisations, perspectives and opinions. Therefore, the conceptual bases of this approach are a lot different from the ones used in quantitative research [23]. When there is not enough theoretical knowledge or precise hypothesis, qualitative research is used to build and comprehend the study object, so hypothesis can be formulated and proved [24]. Since there was not enough literature regarding vocational rehabilitation with individuals with physical and neurological disabilities in Portugal, there was a need for an exploratory research that exposed what is being done and how this is being done. As it is an unexplored territory and only a few niches have been detected in the national context, it is considered that a qualitative approach could be the best option to break ground. Therefore, a qualitative approach was used to build up the foundations for the knowledge on the subject, through the views of those who come closest to the process, particularly the individuals who receive the services and the professionals who deliver them.

The present study has a descriptive-exploratory goal as it tries to describe and comprehend a problem through critical literature review, interviews with participants and an exploration of their insights $[25,26]$. To achieve this, case study research was conducted as it is a qualitative research method that explores, describes [27] and observes an environment or an individual [28] in its real context [27]. Several authors, among them Yin [27] and Stake [29] emphasise that the purpose of a case study is to deepen the understanding of the "how" and the "why" of the case, showing its identity and its own characteristics, specially in the aspects that interest the researcher.

Stanley invokes Patton to refer that a qualitative descriptive approach is appropriate for programmes research. Corresponding research questions might be: "What do the clients think of this service?" "What are the clients' perspectives?" This author also states that qualitative descriptive studies bring great potential to OT research, they are especially appropriate for appraising clients and stakeholders' perspectives on a program, service or topic, and the findings can be used to inform quality improvements, more client-focused services and better targeted services [30].

In qualitative research, participants are included if they are linked to the problem studied and/or if they have knowledge about it [31]. For this study the unit of analysis, the case, was OT's intervention in vocational rehabilitation of individuals with physical and neurological disability. In order for case study research to have a solid foundation it requires data acquired from different sources and through different methods. Thus, it was considered to inquire clients and professionals equally, to gather their singular perspectives as they play different roles in the process. Therefore, participants were clients receiving a vocational rehabilitation programme at CRPG, their Occupational Therapists and other healthcare professionals involved in the rehabilitation process. 
It is the use of these different instruments that, according to Coutinho [32], allow cross-referencing, assure different perspectives of participants and several measures of the same phenomenon, and create the necessary conditions for triangulation and confirmation of validity of the process. The inclusion criteria for clients were: being aged between 18 and 65 years old; having a physical and/or neurological disability; being included in a vocational rehabilitation programme, with OT intervention. The inclusion criteria for Occupational Therapists consisted in providing vocational rehabilitation to these same participants. In the same way, the healthcare professionals were included if they also provided vocational rehabilitation services to the same client(s) and worked with the Occupational Therapists.

Interview and focal group (with audiovisual support) were used to collect data. With the clients, due to more sensitive issues, the option was to resort to single interview to directly access their thoughts in a most unconstrained environment. Accordingly, semi structured interview was selected to assess the participants' perception, thoughts and ideas about OT interventions and relevance in the rehabilitation process. Audiovisual recording allowed to gather information through observation of the individuals' behaviours $[25,33]$.

To elicit information from the team members about the shared, specific and focused issue, in this case working with an OT focus group emerged as the best technique to use. During the focus group, a moderator and an observer were present, to capture and register insights on OT work, on its contributions to team and clients' effort towards vocational rehabilitation, and possibly other contributions that could enrich the data obtained.

In order to achieve the objectives foreseen in the research and to improve the reliability and fluidity of the interviews and focus groups, scripts were created and validated by experts in OT and in research tools development.

The meetings were initiated with the exposure of the study purpose, the guarantee of the confidentiality of the contributions and the request of the permission of each one of the participants, so that the conversations could be recorded.

After data was obtained, qualitative content analysis by Bardin method, was conducted. This method consists in communication analysis techniques that use objective and systematic procedures to analyse data content, based on methodological rigorousness that give scientific validity to the study and overcomes subjectivity in data interpretation [34-36].

WebQDA was the software used for content analysis, where data from each participant was verbatim transcribed and codified simultaneously by three members of the research group (in order to achieve intercoder reliability) in semantic categories and subcategories and according to the rules of exclusivity, homogeneity and pertinence. Categorisation is the process by which raw data is transformed and aggregated into units that allow an accurate description of the relevant characteristics of the content (Holsti, 1969 cited by Bardin [37]). Accordingly, the categories were predetermined when the scripts of data collection instruments were created and also emerged from the data. These were mainly related with perceptions about the knowledge of the OT practice and client's satisfaction. The categories are substantiated with quotations.

The sample included six clients, two Occupational Therapists and three healthcare professionals. Participants main characteristics are presented in the following table (see Table 1). 
Table 1. Corpus

\begin{tabular}{|c|c|c|}
\hline Participant & Information & \\
\hline \multirow[t]{3}{*}{ C1 client } & Biodemographic & Female, 52 years, Unemployed \\
\hline & Diagnosis & Ischemic Cerebral Vascular Accident (CVA)/Stroke \\
\hline & $\begin{array}{l}\text { Rehabilitation } \\
\text { service }\end{array}$ & $\begin{array}{l}\text { Assessment and advisement of self-care products; } \\
\text { Assessment of Activities of Daily Living (ADL) and } \\
\text { 3rd person assistance }\end{array}$ \\
\hline \multirow[t]{3}{*}{ C2 client } & Biodemographic & Female, 39 years, Unemployed \\
\hline & Diagnosis & Epilepsy and non-identified neurodegenerative disease \\
\hline & $\begin{array}{l}\text { Rehabilitation } \\
\text { service }\end{array}$ & Individual intervention for active life \\
\hline \multirow[t]{3}{*}{ C3 client } & Biodemographic & Female, 59 years, (saleswoman) \\
\hline & Diagnosis & Ischemic CVA \\
\hline & $\begin{array}{l}\text { Rehabilitation } \\
\text { service }\end{array}$ & $\begin{array}{l}\text { Individual intervention for active life; Rehabilitation } \\
\text { after acquired brain injury }\end{array}$ \\
\hline \multirow[t]{3}{*}{ C4 client } & Biodemographic & Female, 38 years, Unemployed \\
\hline & Diagnosis & Bilateral transtibial amputation \\
\hline & $\begin{array}{l}\text { Rehabilitation } \\
\text { service }\end{array}$ & Assessment and advisement of self-care products \\
\hline \multirow[t]{3}{*}{ C5 client } & Biodemographic & Male, 20 years, Unemployed \\
\hline & Diagnosis & Cerebral tumor (in remission) \\
\hline & $\begin{array}{l}\text { Rehabilitation } \\
\text { service }\end{array}$ & $\begin{array}{l}\text { Individual intervention for active life; Rehabilitation } \\
\text { after acquired brain injury }\end{array}$ \\
\hline \multirow[t]{3}{*}{ C6 client } & Biodemographic & Female, 47 years, Unemployed \\
\hline & Diagnosis & Cerebral Aneurysm \\
\hline & $\begin{array}{l}\text { Rehabilitation } \\
\text { service }\end{array}$ & $\begin{array}{l}\text { Individual intervention for active life; Rehabilitation } \\
\text { after acquired brain injury }\end{array}$ \\
\hline \multirow{2}{*}{$\begin{array}{l}\text { P1 team } \\
\text { professional }\end{array}$} & Gender & Female \\
\hline & Job & Neuropsychologist \\
\hline \multirow{2}{*}{$\begin{array}{l}\text { P2 team } \\
\text { professional }\end{array}$} & Gender & Male \\
\hline & Job & Speech therapist \\
\hline \multirow{2}{*}{$\begin{array}{l}\text { P3 team } \\
\text { professional }\end{array}$} & Gender & Male \\
\hline & Job & Psychologist \\
\hline \multirow{2}{*}{$\begin{array}{l}\text { OT1 } \\
\text { occupational } \\
\text { therapist }\end{array}$} & Gender & Female \\
\hline & Qualifications & $\begin{array}{l}\text { Bachelor's degree in 2001; Working at CRPG since } \\
1997\end{array}$ \\
\hline \multirow{2}{*}{$\begin{array}{l}\text { OT2 } \\
\text { occupational } \\
\text { therapist }\end{array}$} & Gender & Male \\
\hline & Qualifications & $\begin{array}{l}\text { Bachelor's degree in 2006; Master's degree in OT in } \\
\text { gerontology; Worked in physical rehabilitation and at } \\
\text { CRPG since April } 2016\end{array}$ \\
\hline
\end{tabular}




\section{Results Analysis and Discussion}

Data used to address the research question was devised into content analytical units and codified in the categories demonstrated in Table 2.

Table 2. Codified data in categories

\begin{tabular}{l|l|l}
\hline Categories & Subcategories & Coding rules \\
\hline $\begin{array}{l}\text { Knowledge } \\
\text { of OT }\end{array}$ & Previous knowledge & $\begin{array}{l}\text { References to previous OT contact or } \\
\text { knowledge }\end{array}$ \\
\cline { 2 - 3 } & Present knowledge & References to present OT knowledge \\
\cline { 2 - 3 } Benefits of OT & $\begin{array}{l}\text { References to benefits of OT in promoting } \\
\text { autonomy, return to occupation } \\
\text { (employment), assessment and advisement } \\
\text { of self-care products, comparing to team } \\
\text { professionals }\end{array}$ \\
\hline Client's & $\begin{array}{l}\text { Assessment and Advisement } \\
\text { of Self-Care Products } \\
\text { Satisfaction }\end{array}$ & $\begin{array}{l}\text { References to client's satisfaction with } \\
\text { occupational therapy role in assessment and } \\
\text { advisement of self-care products }\end{array}$ \\
\cline { 2 - 3 } & $\begin{array}{l}\text { Intervention Satisfaction } \\
\text { References to client's satisfaction with } \\
\text { occupational therapy role in overall } \\
\text { rehabilitation }\end{array}$ \\
\hline OT Process & $\begin{array}{l}\text { Meeting Client Needs and } \\
\text { Priorities }\end{array}$ & $\begin{array}{l}\text { References to OT intervention responding } \\
\text { client needs and priorities }\end{array}$ \\
\cline { 2 - 3 } & Promoting Autonomy & $\begin{array}{l}\text { References to OT intervention in promoting } \\
\text { ADL independence }\end{array}$ \\
\cline { 2 - 3 } & Occupation Recovery & $\begin{array}{l}\text { References to OT intervention in occupation } \\
\text { recovery (employment) }\end{array}$ \\
\hline
\end{tabular}

Initially it was compared the previous and the current knowledge that clients had about OT. This data was then compared with the knowledge of other healthcare professionals and confronted with the Occupational Therapists' perspective of what they think the other participants know about their profession.

All CRPG clients had previous contact with OT, in other institutions (C1, C2, C3 and C5) or through friends and/or relatives that previously received OT intervention (C4 and C6). Occupational Therapists referred that clients who had contact with OT before, had difficulties in differentiate Physiotherapy and OT. For example, OT1 mentioned "confusion with OT and Physiotherapy" and OT2 justified this confusion by mentioning that " (...) most of clients' previous intervention was based in rehabilitation services, like in physical medicine rehabilitation centres". The overlap between Physiotherapy and OT had been a point of discussion since the 70's; for example, CVA rehabilitation is one of the main areas where this overlap is verified [38], therefore it was expectable that clients' perception was similar in these two areas.

Occupational Therapists referred differences between OT and the other team members' interventions, mostly because 'the goals are completely different. For example, neuropsychological and OT work is similar in this context but the goals are 
completely different. Just because we use same techniques doesn't mean the final goal will be the same." (OT2). Although this may seem counterintuitive in a rehabilitation process, we believe that the interviewee intended to refer that OT provides expertise in functional assessment and observation and the neuropsychologist uses formal assessments to identify changes in cognitive function or identify preserved functions that can be used in the rehabilitation process. Ultimately, the goals are established accordingly to the client's needs and the team should work together to achieve the same final goal that is employment reintegration.

With regards to current knowledge, clients referred that OT intervenes in ADL and Instrumental Activities of Daily Living (IADL), occupation areas well defined in OT Practice Framework [1]. C2 referenced that OT "helps me walking". Walking matches to occupational area "functional mobility", an ADL, target of OT approach with activities that promote muscle strength and/or tools to help mobility [39, 40].

IADL are domestic activities, such as house management and maintenance $(\mathrm{C} 1$ whishes "to be capable of ironing"); cleaning and preparing meals (C6 refer "sometimes we have to do the lunches"); computer use for communication, work or leisure management (C1 says "OT teaches to write in computer") and social participation, or, in other words, community activities (C6 mentions "sometimes we go out"). IADL also require social and environmental related skills - the Occupational Therapist intervenes directly in these activities when occupational performance is affected, being one of principal and exclusive OT intervention area [41].

About praxis and motor skills improvement, most of inquired referred to the OT role in upper limb re-education. C1 refers that "OT works (...) with upper limbs", C2 mentions that she stopped trembling so much since OT helped in "hands shaking", C3 says "OT is a help to my arm" and "help to hold and pull" and C5 refers his spasticity in upper limb and the Occupational Therapist worked "to open the hand and things like that". The respondents also affirmed that OT intervention area includes body (according to $\mathrm{C} 1$ "OT works the body") and coordination (C1 affirms "OT improves coordination"). As the participants referred, OT intervention improves muscle strength, coordination and dexterity [42]. Work market tendencies and some of population demands, took Occupational Therapists (mainly the ones who work in physical rehabilitation area), to specialise and directing their therapeutic efforts to promote functionality in the upper limb [42-44].

There were also references to OT intervention in cognitive rehabilitation (C6 refers "it is for brain stimulation"). Occupational Therapists have an important role in promoting cognitive function because when deficits are identified, the therapist promotes or maintains a significant and productive life, within client's social and cultural context [45].

Team members mentioned that OT is important in "client's ADL" (P2), allows to have "autonomy in ADL" (P3) and "intervenes in (...) daily life" (P1). There was also mentions to OT approach in skills improvement, like P1 that referred "OT works postures", "gives functionality to the limbs", "gives self-confidence" and "stimulates physical part through motor exercises". P1 added that "working the skills already mentioned is crucial to [vocational] reintegration, once they are connected".

P1 and P2 referred OT broadness of interventions. Also, P3 affirmed "OT potentiates functionality after injury; (...) in functionality assessment or in the design of rehabilitation plans, the Occupational Therapist summarises functional skills profile 
and enhances rehabilitation potential". In fact, OT corresponds to a health field related to client's autonomy, allowing the Occupational Therapist to be the best healthcare professional to assess and summarise functional competence in any area [39, 40].

When asked about their perception concerning what others think about their work, OT1 refers "clients know my job", and added "that makes me feel fulfilled". Clients and healthcare professionals referred OT intervention advantages, identifying the use of assistive products, as described by literature [46]. Thus, C1 referred "Occupational Therapist knew products I need". Also, P3 stated "the Occupational Therapist is essential to give functionality, because we need to know what the client stopped doing, what activities can be recovered and what cannot. Thereafter, we can understand what assistive products can be useful for each client". P3 continued saying that "Occupational Therapists give clients assistive products, and they always know a lot of possible devices that we never heard of. This helps clients understanding that they can become functional again".

CRPG clients interviewed about assessment and advisement for assistive products were satisfied - C1 revealed "the electric wheelchair will allow me to be more independent, specially outside, because I do not have to put so much effort like I do with the manual one"; C4 stated "the therapist was really thoughtful and recommended the most suitable wheelchair". Assistive products are important for clients' functionality [42] and to improve occupational performance in work activities, because they can promote job opportunities and provide employment for people with disabilities [10]. When needed, Occupational Therapists use assistive products and/or materials and tools adaptations, that allow clients to perform their activities and create an accessible environment [42, 47, 48].

P1 referred "the Occupational Therapist has a relevant and complementary role (...) with several strategies that are transferred to the other team members". Complementary role with multidisciplinary team was also confirmed by some clients, like $\mathrm{C} 4$ that affirmed "the Occupational Therapist has a broad vision that can suppress needs we might have".

Team members referred the importance of including an Occupational Therapist in the team:

- P2, the Speech and Language Therapist, said "OT intervention is more comprehensive, unlike speech therapists, for example, that know specifically about speech";

- P1, the Neuropsychologist, referred "the assessment of the Occupational Therapist is key, because it provides essential information to the team";

- P3, the Psychologist, affirmed "nowadays, the Occupational Therapists' opinions and suggestions about adaptations are supported by scientific statements".

Regarding OT intervention satisfaction, clients' opinion was good and positive (C1, $\mathrm{C} 2, \mathrm{C} 3$ and C4). Some clients recommended it because it was beneficial for them (C2, C3, C4 and C6). One client mentioned improvements with OT intervention - C2 stated "since I have OT, I can see improvements [on upper limb] and so can the therapist".

Some clients also referred work integration through internship programmes, like C5 "I applied to an internship within my rehabilitation process". C5 wanted to be in hotel business, but could only do tasks related to greeting customers, recognising the needs 
of tasks adaptations to integrate workplace. Adjusting tasks in order to make them more attuned to the client's capabilities is one of the OT competencies that is easily transferred into the workplace [49].

From the team members' perspective, OT can promote work integration by recommending assistive products, teaching strategies to employers, "can give a job to someone that wasn't functional before" (according to P3) or by direct intervention "in work context" (according to P2). The OT goal, in vocational rehabilitation, is promoting work inclusion for people with disability by, for example, adjusting clients to the task or vice-versa [49].

It was also mentioned that non-working related skills improvement could "increase productivity and allow an individual to engage in a job" (according to P3). According to evidence, young adults who were part of a vocational rehabilitation, with a multidisciplinary team, had improved occupational performance in work, leisure and self-care [3].

OT is crucial to allow improvement on client's autonomy on a number of different activities - C2 refers "I love knitting and OT helps a lot"; C5 states "I can tie my shoes now". Clients also observe results on skills improvement, like C1 "OT helped me control my hands" and C2 "now I have balance (...) so I feel more active". There were also references regarding global autonomy - C6 affirmed "I became more independent".

The healthcare professionals said that clients who had OT intervention "had better upper limb skills", were more independent in "ADL, like lunch" and had "better quality of life" (P3) These are well described OT interventions [50, 51].

According to Occupational Therapists' perspective, there are autonomy improvements - OT2 confirmed "they leave here doing a lot more and we can see results".

CRPG intervention responds to clients' priorities and needs, according to OT1 that affirmed "when Occupational Therapists do not know, they search for the answer". Some clients also mentioned OT answers their personal goals and respects their interests, like C6 that affirmed "helps me (...) give strategies to achieve what I want" and "my interests are being respected".

Occupational Therapists search for client's life experience, expectations and goals. Afterwards, they use their knowledge about how occupational engagement affects health, wellbeing and participation. Therefore, they observe, analyse, describe and interpret occupational performance and identify, both with clients and caregivers, the intervention process [1].

\section{Conclusion}

Comparing the research results with international literature, it was verified that clients and team members' perspectives correspond to Occupational Therapist skills and intervention, in a vocational rehabilitation programme. Most of the clients associated OT with autonomy, functionality and satisfactory occupational performance in ADL, IADL and work, which are recognised areas of OT intervention in vocational rehabilitation.

Clients and other healthcare professionals recognize the work tools of the Occupational Therapists and their competencies. Their wide range of knowledge contribute 
to a unique professional profile in the vocational rehabilitation field either through their particular experience in the use and study of activities, or by the way in which they perceive the complexity and uniqueness of individuals and how they relate to work in its biopsychosocial dimensions.

Study results allowed to describe and explore clients and other team members' perspectives about OT intervention in vocational rehabilitation, as well as to understand how OT intervention contributes to the clients' occupational performance.

It was observed that, in Portugal, a very a small number of institutions are intended to provide vocational rehabilitation services, however only one, CRPG, is currently providing this type of programmes in this area. It was also found the need for greater disclosure of the OT intervention in vocational rehabilitation, according to the other team members' perspective. Considering the favourable results of OT intervention with clients' occupational performance, it would be beneficial to increase the number vocational rehabilitation centres with specialized Occupational Therapists. It was also pertinent to verify that the link between the Occupational Therapist and the employer influences clients' productivity in the work context.

Finally, it can be seen that the different participants, clients and team members, in the study agree that the existence of a professional with an Occupational Therapist competence profile is an asset and enhances the rehabilitation potential of those seeking rehabilitation and vocational training services with the aim of reintegrating in the labour market.

It would be beneficial for collective knowledge to explore more contexts in vocational therapy, in Portugal, with OT intervention, to gather a more comprehensive information about this topic.

Acknowledgments. This paper is the result of a research work that involved students and professors of the Bachelor's Degree in Occupational Therapy of the School of Health Sciences of the Polytechnic of Leiria - Portugal - academic year 2015-2016. The authors acknowledge the collaboration of the Centro de Reabilitação Profissional de Gaia, in particular it's Occupational Therapists.

\section{References}

1. American Occupational Therapy Association: Occupational Therapy practice framework: Domain \& process, 3rd edn. American Journal of Occupational Therapy, 2nd edn., vol. 68 (2014)

2. Ross, J.: Occupational Therapy and Vocational Rehabilitation. John Wiley \& Sons Ltd., West Sussex (2007)

3. Verhoef, J., Roebroeck, M., van Schaardenburgh, N., Floothuis, M., Miedema, H.: Improved occupational performance of young adults with a physical disability after a vocational rehabilitation intervention. J. Occup. Rehabil. 24(1), 42-51 (2014)

4. Söderback, I. (ed.): International Handbook of Occupational Therapy Interventions. Springer, London (2009)

5. Desiron, H., de Rijk, A., Van Hoof, E., Donceel, P.: Occupational therapy and return to work: a systematic literature review. BMC Public Health 11(1), 615 (2011) 
6. Escorpizo, R., Brage, S., Homa, D., Stucki, G.: Handbook of Vocational Rehabilitation and Disability Evaluation: Application and Implementation of the ICF. Springer, New York (2014)

7. Foy, C.: Long term efficacy of an integrated neurological and vocational rehabilitation programme for young adults with acquired brain injury. J. Occup. Rehabil. 24(3), 533-542 (2014)

8. Godinho, F., Santos, C., Coutinho, A., Trigueiros, P.: Tecnologias de informação sem barreiras no local de trabalho. UTAD, Vila Real (2004)

9. Direção Geral do Património Cultural: Acessibilidades. http://www.patrimoniocultural.pt/pt/ publicos/visitantes-com-acessibilidade-reduzida/

10. Junça, M., Ferreira, I.: Superar barreiras nos postos de trabalho: O impacto das tecnologias de apoio no desempenho ocupacional. Escola Superior de Saúde do Alcoitão (2006)

11. Barreto, M., Alves, M., Vasconcelos de Morais, G.: A Acessibilidade nas Empresas: Percepção dos Portadores de Deficiência Visual Inseridos no Mercado de Trabalho (2012)

12. Brennan, B., Corcoran, O., Irudayaraj, B., Kearney, S., Kelley, V., Lyons, E.: Handbook for Occupational Therapists - Vocational Rehabilitation for Clients with Chronic Pain and Musculoskeletal Disorders in Ireland. Association of Occupational Therapists of Ireland, Dublin (2012)

13. Department for Work and Pensions: Building capacity for work: a UK framework for vocational rehabilitation. Department for Work and Pensions (2004)

14. Decreto-Lei n. ${ }^{\circ}$ 93/2009: Diário Da República, $1^{\text {a }}$ Série de 16 Abril, 1(74), 2275-2277 (2009)

15. Cook, A., Polgar, J., Hussey, S.: Hussey's Assistive Technologies: Principles and Practice. Mosby Elsevier (2008)

16. Arango-soler, J., Santander, J.: Programa de orientación vocacional laboral para personas con discapacidad de la fundación de adaptación laboral. Rev. Salud Publica 14(5), 842-851 (2012)

17. World Federation of Occupational Therapists: Position Statements - Vocational Rehabilitation. http://www.wfot.org/aboutus/positionstatements.aspx

18. Arikawa, M., Goto, H., Mineno, K.: Job support by occupational therapists for people with developmental disabilities: two case studies. Work 45, 245-251 (2013)

19. Main, L., Haig, J.: Occupational therapy and vocational rehabilitation: an audit of an outclient occupational therapy service. Br. J. Occup. Ther. 69(6), 288-292 (2006)

20. Waddell, G., Burton, K., Kendall, N.: Vocational Rehabilitation - What works, for whom, and when? Department of Work and Pensions (2013)

21. Sandqvist, J., Gullberg, M., Henriksson, C., Gerdle, B.: Content validity and utility of the assessment of work performance (AWP). Work J. Prev. Assess. Rehabil. 30(4), 441-450 (2008)

22. Centro de Reabilitação Profissional de Gaia CRPG. http://www.crpg.pt/Paginas/home.aspx

23. Bassora, J., Campos, C.: Metodologia clínico-qualitativa na produção científica no campo da saúde e ciências humanas: uma revisão integrativa. Revista Eletrônica de Enfermagem 12(4), 753-760 (2010)

24. Serapioni, M.: Métodos qualitativos e quantitativos na pesquisa social em saúde: algumas estratégias para a integração. Ciência \& Saúde Coletiva 5(1), 87-192 (2000)

25. Gerhardt, T., Silveira, D.: Métodos de Pesquisa. Universidade Federal do Rio Grande do Sul, Porto Alegre (2009)

26. Gil, A.: Como Elaborar Projetos de Pesquisa, 4th edn. Atlas, São Paulo (2007)

27. Yin, R.: Estudo de Caso: Planejamento e Métodos. Bookman editora, Porto Alegre (2015)

28. Chizzotti, A.: Pesquisa Qualitativa Em Ciências Humanas e Sociais. Vozes, Petrópolis (2006) 
29. Stake, R.: A arte da investigação com estudos de caso. Fundação Calouste Gulbenkian, Lisboa (2007)

30. Stanley, M.: Qualitative Descriptive: A Very Good Place to Start. Qualitative Research Methodologies for Occupational Science and Therapy, pp. 21-36. Routledge, Abingdon (2015)

31. Turato, E.: Métodos qualitativos e quantitativos na área da saúde: definições, diferenças e seus objetos de pesquisa. Revista de Saúde Pública 39(3), 507-514 (2005)

32. Coutinho, C.: Metodologias de Investigação em Ciências Humanas. Almedina, Coimbra (2011)

33. Duarte, R.: Interviews in qualitative research, pp. 213-225. Educar (2004)

34. Freitas, H., Moscarola, J.: Da observação à decisão: métodos de pesquisa e de análise quantitativa e qualitativa de dados. RAE-Eletrônica 1(1), 30 (2002)

35. Gondim, S., Bendassolli, P.: The use of the qualitative content analysis in psychology: a critical review. Psicologia Em Estudo 19(2), 191-199 (2014)

36. Silva, A., Moura, G., Cunha, D., Gaspary, E.: Análise de conteúdo: fazemos o que dizemos? Um levantamento de estudos que dizem adotar a técnica. IV Encontro de Ensino E Pesquisa Em Administração E Contabilidade, pp. 1-14 (2013)

37. Bardin, L.: Análise de conteúdo. Edições 70, Lisboa (2015)

38. Booth, J., Hewison, A.: Role overlap between occupational therapy and physiotherapy during in-client stroke rehabilitation: an exploratory study. J. Interprof. Care 16(1), 31-40 (2002)

39. Jardim, T., Afonso, V., Pires, I.: A terapia ocupacional na Estratégia de Saúde da Família evidências de um estudo de caso no município de São Paulo. Rev. Ter. Ocup. Univ. São Paulo 19(3), 167-175 (2008)

40. Pedretti, L., Pendleton, H., Schultz-Krohn, W.: Pedretti's Occupational Therapy: Practice Skills for Physical Dysfunction, 7th edn. Mosby Elsevier (2012)

41. Schwanke, C.: Atualizações em geriatria e gerontologia IV: aspectos demográficos, biopsicossociais e clínicos do envelhecimento, 4th edn. Edipucrs, Porto Alegre (2012)

42. Yeng, L., Stump P., Hideko, H., Kaziyama, S., Teixeira, M., Imamura, M., Greve, A.: Medicina física e reabilitação em doentes com dor crônica. Rev. Med. (São Paulo) 80(2), 245-255 (2001)

43. Carlo, M., Bartalotti, C.: Terapia ocupacional no Brasil: fundamentos e perspectivas. Plexus (2001)

44. Ribeiro, S., Guimarães, E., Maria, A., Novais, V., Aspectos, M.: Aspectos relacionados ao processo de retorno ao trabalho de indivíduos com desordens musculoesqueléticos do membro superior: uma bibliografia comentada. Revista de Terapia Ocupacional Da Universidade de São Paulo 18(1), 38-43 (2007)

45. Loureiro, A., Lima, A., All, E.: Reabilitação cognitiva em idosos institucionalizados: um estudo piloto. Revista de Terapia Ocupacional da Universidade de São Paulo 22(2), 136-144 (2011)

46. Emiliani, P.L., Burzagli, L., Como, A., Gabbanini, F., Salminen, A.L. (eds.): Association for the Advancement of Assistive Technology in Europe: Assistive technology from adapted equipment to inclusive environments: AAATE 2009. IOS Press (2009)

47. American Occupational Therapy Association: Specialized Knowledge and Skills in Technology and Environmental Interventions for Occupational Therapy Practice. Am. J. Occup. Ther. 64(6Suppl.), S44-S56 (2010)

48. Lindôso, Z., Ferreira, E., Schwanke, C.: A importância da terapia ocupacional na reabilitação das atividades de vida diária e instrumentais do idoso. In: Schwanke, C. (ed.) Atualizações em geriatria e gerontologia IV: aspectos demográficos, biopsicossociais e clínicos do envelhecimento, p. 437. Edipucrs (2012) 
49. Lancman, S., Ghirardi, M.: Pensando novas práticas em terapia ocupacional, saúde e trabalho. Rev. Ter. Ocup. Univ. São Paulo 13(2), 44-50 (2002)

50. Jurdi, S., Brunello, B., Honda, M.: Terapia ocupacional e propostas de intervenção na rede pública de ensino Occupational therapy and a proposal intervention in a public school. Rev. Ter. Ocup. Univ. São Paulo 15(1), 26-32 (2004)

51. Malfitano, A.: Campos e núcleos de intervenção na terapia ocupacional social. Revista de Terapia Ocupacional Da Universidade de São Paulo 16(1), 1-8 (2005) 